DOI: 10.17951/lrp.2019.38.4.125-141

\author{
Magdalena BoczKowsKa \\ Uniwersytet Marii Curie-Skłodowskiej \\ ORCID - 0000-0003-3435-8193
}

\title{
POJĘCIE RESILIENCE \\ W UJĘCIU TRADYCYJNYM I WSPÓŁCZESNYM
}

\begin{abstract}
Streszczenie: W niniejszym artykule zarysowano koncepcję resilience, która w szerokim ujęciu dotyczy możliwości adaptacyjnych jednostek, rodzin czy całych społeczności w obliczu doświadczanych przeciwności losu lub traumatycznych zdarzeń. Wyjaśniono genezę koncepcji, a także wskazano na etymologię tego pojęcia. Wskazano Normana Garmezy'ego, Emmy Werner i Michaela Ruttera jako prekursorów badań nad resilience, dokonano także syntetycznego opisu prowadzonych przez nich badań. Podjęte w artykule rozważania mają na celu ukazanie złożoności samego konstruktu resilience, oraz związanych z nim pojęć pozytywnej adaptacji, czynników ryzyka i czynników chroniących. Przeanalizowano także możliwości poznawcze i ograniczenia w wykorzystywaniu koncepcji resilience, akcentując konieczność ustalenia jednolitych ram teoretyczno-empirycznych.
\end{abstract}

Słowa kluczowe: resilience, pozytywna adaptacja, czynniki ryzyka, czynniki chroniące

\section{RESILIENCE - GENEZA POJĘCIA \\ I ZAINTERESOWAŃ BADAWCZYCH}

Pojęcie resilience stanowi obszar zainteresowań psychologii i pedagogiki zdrowia, psychiatrii, interwencji kryzysowej, psychologii pozytywnej od ponad 50 lat. Wiele dekad wcześniej poszukiwano odpowiedzi na pytanie, dlaczego niektóre jednostki, mimo poważnych życiowych wyzwań i przeżyć, są w stanie odpowiednio przystosować się i pozytywnie funkcjonować. Badacze próbowali zrozumieć, jakie naturalne mechanizmy pozwalają ludziom radzić sobie w obliczu przeciwności losu i po ich doświadczeniu oraz dlaczego niektóre jednostki czy rodziny wydają się bardziej podatne na konsekwencje negatywnych życiowych zdarzeń niż inne, które okazują się lepiej przed nimi chronione (Masten 2018). 
Konieczność lepszego zrozumienia procesów adaptacyjnych jednostki, rodzin czy całych społeczności zrodziła się na skutek globalnych nieszczęść związanych przede wszystkim z wojnami światowymi oraz Wielkim Kryzysem. Następstwa tych wydarzeń dotknęły miliony dzieci i rodzin na całym świecie, co zainspirowało badaczy do poszukiwania odpowiedzi na pytanie, w jaki sposób tak traumatyczne przeciwności losu zagrażają adaptacji człowieka i co można zrobić, aby zwiększyć jego możliwości adaptacyjne. Badaniom wówczas poddawano osoby i rodziny, które doświadczyły różnego rodzaju traumatycznych zdarzeń - przemocy, separacji, tortur, bezdomności, konsekwencji katastrof gospodarczych, naturalnych i politycznych (Masten i in. 2015). Zauważono, że w wielu przypadkach jednostka narażona na długotrwały, silny stres poddaje się i nie podejmuje zachowań, które pozwoliłyby jej przystosować się i aktywnie działać. Niektóre jednostki natomiast są w stanie nie tylko przystosować się do funkcjonowania w czasie doświadczanej traumy, ale także wykorzystać ją tak, aby prowadzić jeszcze bardziej satysfakcjonujące życie niż wcześniej.

Systematyczną teorię i badania nad resilience można datować na lata 70 . XX wieku. Były one poprzedzone dziesięcioleciami obserwacji, teorii, badań i praktyki dotyczących wpływu traumatycznych zdarzeń na funkcjonowanie oraz rozwój jednostek i rodzin (Masten 2001; Masten, Cicchetti 2016; Walsh 2016). Dociekania badawcze związane z indywidualną odpornością pojawiły się w naukach klinicznych dotyczących wpływu przeciwności losu na zdrowie psychiczne i rozwój, a mających na celu zrozumienie przyczyn i etiologii zaburzeń psychicznych (Masten 1989). Początkowo poszukiwania badawcze koncentrowały się głównie na negatywnych konsekwencjach doświadczanych przez jednostkę przeciwności losu - postrzegano je jako czynniki ryzyka dla psychopatologii, dysfunkcji, załamania i innych problematycznych rezultatów (Gottesman 1974; Masten, Cicchetti 2016). Badaczy zainteresowało jednak, co decyduje o tym, że niektóre dzieci lub rodziny w obliczu traumy lub stresujących zdarzeń pozytywnie przystosowują się i łagodzą skutki ryzyka i przeciwności losu. Zaobserwowano, że spora grupa dzieci pomimo doświadczenia przeciwności losu i zagrożeń rozwija się normalnie (Garmezy 1971; Rutter 1979). Ścieżki rozwoju dzieci były bardzo zróżnicowane - od osiągania ponadprzeciętnych sukcesów, przez dobrą adaptację społeczną, po złe lub bardzo złe przystosowanie społeczne. Badacze (Garmezy 1971; Rutter 1979) stwierdzili, że koncentrowanie się jedynie na czynnikach ryzyka i ich negatywnych następstwach prowadzi do nadmiernego pesymizmu i minimalizowania znaczenia czynników i mechanizmów chroniących.

Elwyn James Anthony, Norman Garmezy, Emmy Werner (za: Martin, Nojoroge 2005) uznali znaczenie zmienności w funkcjonowaniu adaptacyjnym i przebiegu życia młodych ludzi uważanych za „zagrożonych” ze względu na ich rodzinę, 
genetykę, narażenie na traumę lub ubóstwo. Doszli do przekonania, że koncentrowanie się jedynie na ryzyku i procesach patologicznych jest niewystarczające i musi istnieć czynnik mający wpływ na radzenie sobie i pozytywną adaptację w grupach ryzyka. Na początku zjawisko to było określane jako odporność na stres lub niewrażliwość, jednak oba te terminy okazały się niewystarczające, dlatego też zdecydowano się na przyjęcie terminu resilience, odnosząc się do szerokiego spektrum badania możliwości, procesów i wyników oznaczonych pożądaną adaptacją w kontekście ryzyka lub przeciwności związanych z dysfunkcją lub problemami z dostosowaniem (Masten, Tellegen 2012).

W ostatniej dekadzie wzrosło zainteresowanie badaniami nad resilience w wielu dyscyplinach naukowych (Henry, Morris, Harrist 2015; Southwick i in. 2014; Walsh 2016). Ma to związek z globalnymi zagrożeniami cywilizacyjnymi - zmiany klimatu, katastrofy naturalne, klęski gospodarcze, wojny i terroryzm - w ich obliczu będzie wymagana wysoka odporność, aby móc poradzić sobie zarówno w wymiarze jednostkowym, jak i globalnym. Mimo że systematyczna teoria i badania nad resilience pojawiły się pół wieku temu, współcześnie zaistniała nowa potrzeba włączenia ich do nauki i praktyki.

Koncepcja resilience tworzy wspólne ramy dla dwóch odrębnych podejść w psychologii zdrowia: za sprawą czynników ryzyka łączy podejście patogenetyczne z salutogenetycznym bazującym na czynnikach ochronnych. Fenomen zjawiska resilience polega przede wszystkim na pozytywnym podejściu do myślenia o rozwoju, zarówno w wymiarze jednostkowym, rodzinnym, jak i społecznym oraz na podkreśleniu znaczenia czynników ochronnych mających związek z pozytywną adaptacją w obliczu zagrożeń i traumatycznych doświadczeń.

\section{PREKURSORZY BADAŃ NAD RESILIENCE}

Opisując fenomen zjawiska resilience należy wspomnieć o pionierskich badaniach w tym zakresie. Norman Garmezy (1985), psycholog kliniczny, pionier w badaniach nad ryzykiem i odpornością, w latach 60 . XX wieku prowadził projekt badawczy pod nazwą Project Competence Longitudinal Study (PCLS). Projekt dotyczył funkcjonowania dzieci matek ze schizofrenią, żyjących w trudnych, niesprzyjających warunkach, często w ubóstwie. W początkowej fazie zespół badaczy interesowało przede wszystkim, w jakim stopniu badane dzieci są narażone na schizofrenię i psychopatologię. W trakcie badań zaobserwowano, że część dzieci pomimo narażenia na wymienione czynniki ryzyka, rozwijała się prawidłowo. Zespół badawczy Garmezy’ego zaczął poszukiwać czynników, czy też mechanizmów, które mogły mieć na to wpływ. W trakcie badań wielokrotnie porównywano 
prawidłowo rozwijające się dzieci z grupy kontrolnej z trzema grupami dzieci narażonych na czynniki ryzyka - będących dziećmi matek ze schizofrenią, depresją i zaburzeniami osobowości. Około połowa badanych dzieci wykazywała dość dobre przystosowanie i nie przejawiała objawów psychopatologii. W dorosłości dzieci te odnosiły sukces życiowy - posiadały dobrą pracę, zamieszkiwały w bezpiecznych dzielnicach, reprezentowały niski wskaźnik rozwodów oraz brak zaburzeń psychicznych. Aby opisać zidentyfikowane przez zespół Garmezy’ego zjawisko pozytywnego funkcjonowania badanych pomimo ekspozycji na czynniki ryzyka użyto angielskiego terminu invulnerability, co można przetłumaczyć jako niezniszczalność. Garmezy wyróżnił trzy grupy czynników ochronnych działających w przypadku tej grupy badanych. Były to cechy osobowościowe, harmonia rodzinna oraz systemy zewnętrznego wsparcia.

Kolejne badania o charakterze longitudinalnym prowadziła Emmy Werner (2005) wraz z zespołem pediatrów, psychologów, psychiatrów i pracowników socjalnych w latach 1955-1995 w populacji dzieci urodzonych w 1955 roku na hawajskiej wyspie Kauai. Zespół badawczy Werner zbierał dane dotyczące badanych dzieci zaraz po urodzeniu, a następnie w 1., 2., 10., 18., 32. i 40. roku życia. Około $30 \%$ osób z grupy badanych urodziło się lub wychowało w ubóstwie, doświadczyło komplikacji przed- lub okołoporodowych, żyło w rodzinach dotkniętych przewlekłą niezgodą, rozwodem lub psychopatologią rodziców, było wychowywanych przez matki, które ukończyły mniej niż 8 klas. W przypadku 2/3 dzieci, które doświadczyły co najmniej czterech spośród wymienionych czynników ryzyka w dwóch pierwszych latach swojego życia, w wieku 10 lat wystąpiły problemy związane z nauką i zachowaniem, a w wieku 18 lat - problemy z prawem i problemy psychiczne. Około 1/3 badanych dzieci, pomimo narażenia na czynniki ryzyka, odniosła sukces życiowy - zarówno w środowisku szkolnym, rodzinnym oraz w relacjach interpersonalnych. Osiągnięcia edukacyjne i zawodowe tych osób były zbliżone, a nawet wyższe w porównaniu do osób, które dorastały w bezpieczniejszych i bardziej stabilnych warunkach. Wnioski z tych badań dotyczyły przede wszystkim znaczenia czynników chroniących: rodzinnych (posiadanie przynajmniej jednej osoby dorosłej zapewniającej poczucie bezpieczeństwa rodzica), społecznych (przynależność do takich grup społecznych, jak szkoła lub kościół) oraz indywidualnych (wewnętrzne poczucie kontroli, pozytywny obraz siebie). Pomimo doświadczania trudnych zdarzeń i warunków życia, wymienione czynniki mogą działać jak bufor, zmniejszający prawdopodobieństwo rozwoju psychopatologii. Do opisu pozytywnej adaptacji tych dzieci Werner użyła terminu resilience.

Z kolei Michael Rutter (1979) przeprowadził badania wśród dzieci zagrożonych zwiększonym prawdopodobieństwem wystąpienia zaburzeń psychicznych. 
Badania prowadzono na wyspie Wight oraz w centrum Londynu. Rutter zidentyfikował zmienne, które w sposób istotny zwiększały prawdopodobieństwo wystąpienia zaburzeń psychicznych u badanych. Były to problemy małżeńskie rodziców, niski status socjo-ekonomiczny rodziny, funkcjonowanie w rodzinie wielodzietnej, przestępczość rodziców, zaburzenia psychiczne matek, bycie pod opieką instytucjonalną. Rutter zdefiniował również czynniki, które w znacznym stopniu zmniejszały prawdopodobieństwo wystąpienia zaburzeń psychicznych. Zaliczył do nich pozytywne cechy temperamentu, płeć żeńską, pozytywne relacje rodziców z dziećmi, przyjazne środowisko szkolne oraz troskliwych nauczycieli. Rutter podkreślał, że zamiast skupiania się na czynnikach i mechanizmach ryzyka, należy koncentrować się na czynnikach i procesach ochronnych. Badacz wskazał, że resilience najlepiej rozpatrywać w kontekście procesu. Zdefiniował on sześć znaczących predyktorów resilience. Są to:

1. Stresory (ang. stressors) - uaktywniają proces resilience i powodują zakłócenie homeostazy u jednostki, grupy lub całego społeczności, postrzeganie czynników stresowych może różnić się ze względu na różny punkt widzenia danej osoby.

2. Zewnętrzny kontekst środowiskowy (ang. the External Environmental Context) - równowaga czynników ryzyka i czynników ochronnych w środowisku dziecka, na przykład w szkole.

3. Proces interakcji człowiek - środowisko (ang. Person-Environment Interactional Processes) - proces między dzieckiem a jego otoczeniem, dziecko może biernie odbierać sytuację, w której się znajduje, albo stara się w niej aktywnie uczestniczyć - zrozumieć i przezwyciężyć trudne zdarzenia, których doświadcza.

4. Charakterystyka wewnętrzna (ang. Internal SelfCharacteristics) - są to siły duchowe, poznawcze, behawioralne, fizyczne, emocjonalne, które są niezbędne do odniesienia sukcesu w różnych warunkach.

5. Procesy resilience - to krótkoterminowe lub długoterminowe procesy resilience lub radzenia sobie, które jednostka nabywa podczas stopniowego doświadczania narastających negatywnych zdarzeń lub stresorów.

6. Pozytywne wyniki (ang. Positive Outcomes) - pozytywna adaptacja życiowa, niezależnie od doświadczanych traumatycznych zdarzeń, stanowi czynnik zwiększający szanse na sukces w późniejszym życiu w obliczu negatywnych wydarzeń (Rutter 1987).

Pionierskie badania Garmezy'ego, Werner i Ruttera nad resilience zmieniły postrzeganie tego zjawiska jako indywidualnej cechy jednostki na korzyść ujmowania go w kategoriach wielowymiarowego procesu, w którym czynniki osobowościowe, rodzinne i pozarodzinne wzajemnie się nakładają i oddziałują na siebie. Aby zrozumieć złożoność znaczeniową konstruktu resilience, należy poddać rozważaniom, jak zmieniało się postrzeganie tego w kolejnych latach. 


\section{RESILIENCE - ROZWAŻANIA TERMINOLOGICZNE}

Angielski termin resilience pochodzi od łacińskiego czasownika salire (sprężynować, powstać) i resilire (odskakiwać, powracać do poprzedniego stanu). Pojęcie oznacza własność fizyczną ciał stałych. Ciało stałe podlegające działaniu siły zewnętrznej ulega zniekształceniu. Jeżeli po ustaniu działania sił powodujących odkształcenie wraca ono do swojego pierwotnego kształtu i wymiaru - mówimy wówczas, że jest ono resilience, co w języku polskim oznacza sprężystość. Podkreśla się, że żadne ciało nie jest idealnie sprężyste - ciała stałe tracą tę właściwość, jeżeli siły powodujące odkształcenie są na tyle duże, że zostanie przekroczona granica sprężystości i powstanie trwałe odkształcenie (Herman, Kalestyński, Widomski 2012).

Termin resilience został zaczerpnięty zatem z nauk fizycznych na określenie zdolności przedmiotów do powrócenia do pierwotnego kształtu po doznaniu odkształcenia na skutek zadziałania jakiejś siły na dany przedmiot. Tę fizyczną zdolność próbuje się przenieść do dyscyplin humanistycznych czy społecznych, upatrując $\mathrm{w}$ resilience, definiowanym jako springing back from adversity (odskakiwanie od przeciwności), zdolności powrócenia do stanu równowagi i pozytywnej adaptacji po doświadczeniu przez jednostkę, rodzinę lub grupę społeczną stresujących lub traumatycznych przeżyć. W naukach społecznych termin ten został zapożyczony przez pionierów badań nad zjawiskiem - Werner, Garmezy, Rutter (Ogińska-Bulik, Juczyński 2011).

Termin resilience w polskiej literaturze przedmiotu bywa tłumaczony w różny, nie zawsze tożsamy, sposób: sprężystość (Szwajca 2014), sprężystość psychiczna (Kaczmarek 2011), odporność na zranienie (Ryś, Trzęsowska-Greszta 2018), prężność (Ogińska-Bulik, Juczyński 2011), prężność osobowa (Uchnast 1998), ale również: zaradność, elastyczność, giętkość, odbojność, odporność, odporność psychiczna, odporność na zranienie, plastyczność, wytrzymałość, zaradność, zdolność do adaptacji czy też spolszczona wersja - rezyliencja (Junik 2011).

Pojęcia te jednak nie odzwierciedlają w pełni angielskiego terminu. Podkreśla się zarówno ilościowe, jak i jakościowe różnice między stosowanymi terminami. Sprężystość to zdolność do odzyskiwania pierwotnego kształtu przy zachowaniu energii. Elastyczność to możliwość odwracalnej zmiany kształtu pod wpływem działających sił - często utożsamiana jest ze sprężystością. Odbojność natomiast to zdolność powrotu do formy wyjściowej po ściśnięciu. Prężność należy rozumieć jako właściwość cieczy oznaczającą ciśnienie, jakie wywierają pary danej substancji będące $\mathrm{w}$ równowadze termodynamicznej z cieczą (Junik 2011). To pojęcie uważa się za najmniej trafne w definiowaniu resilience. Autorzy publikacji nie zawsze uzasadniają wybór polskiego pojęcia jako odpowiednika resilience w swoich dociekaniach badawczych, co z kolei powoduje pewien chaos terminologiczny i utrudnia 
stworzenie jednolitych, poprawnych metodologicznie ram do badań. W związku z tym Wioletta Junik (2011) proponuje, aby używać oryginalnego terminu lub jego spolszczonej wersji. Zdaniem autorki ułatwi to między innymi śledzenie polskiego dorobku naukowego z zakresu resilience oraz inter- $\mathrm{i}$ transdyscyplinarne rozważania naukowe czy też poszukiwania badawcze.

Znaczenie terminu resilience zmieniało się wraz z rozwojem i gromadzeniem wiedzy o samym zjawisku. Angielski termin resilience opisuje wiele możliwości pozytywnego przystosowania się w sytuacji negatywnych, a nawet traumatycznych zdarzeń poprzez umiejętne radzenie sobie, a także zdobywanie nowych doświadczeń i wiedzy prowadzące często do lepszego i bardziej satysfakcjonującego życia. Termin resilience według American Psychological Association to proces dostosowywania się jednostki w obliczu przeciwności losu, traumy, tragedii, zagrożeń (Reid). Definicja ta wskazuje na ogólny zarys koncepcji resilience, jednak nie odzwierciedla złożonej natury resilience. W szerokim ujęciu resilience może być definiowane jako potencjał żywego systemu, który jest w stanie dobrze radzić sobie z poważnymi trudnościami zagrażającymi jego stabilności, wydajności i rozwojowi (Sapienza, Masten 2011).

Resilience jest przez naukowców różnorodnie postrzegane i definiowane jako cecha, proces, wynik lub model przebiegu życia (Luthar 2006; Masten, Best, Garmezy 1990; Masten, Cicchetti 2016).

Resilience jest definiowane w kategorii indywidualnej cechy/kompetencji/ zdolności jednostki lub ich pewnej kombinacji. Może być zatem ujmowane jako zdolność „odbijania się od dna”, czyli powrotu do zdrowia psychicznego i pozytywnego funkcjonowania po doświadczeniu stresującego zdarzenia. Podkreśla się jednak, że zdolność ta nie jest taka sama w całym przebiegu życia, a także nie dotyczy wszystkich sfer funkcjonowania jednostki. Przykładowo osoba, która doświadczyła traumatycznego przeżycia (śmierć rodzica, rozwód, klęska żywiołowa) może pozytywnie funkcjonować w sferze zawodowej, a negatywne konsekwencje psychiczne mogą dotyczyć sfery rodzinnej. Może być również tak, że w jednym okresie życia jednostka będzie potrafiła pozytywnie przystosować się po ekspozycji na silnie stresujące zdarzenie, a $\mathrm{w}$ innych okolicznościach może poddać się bez nadziei na poprawę swojego życia (Rutter 1987). Block i Kremen (1996) użyli terminu ego-resiliency (z ang. prężność ego), definiując je jako adaptacyjną elastyczność wynikającą z indywidualnej zdolności kontrolowania swoich emocji i zachowań w różnych sytuacjach. Prężność ego to zespół pewnych właściwości osobowościowych, umiejętności, kompetencji, które umożliwiają radzenie sobie w trudnych sytuacjach (Heszen, Sęk 2007). Ego-resiliency jako indywidualna cecha może występować pomimo braku ekspozycji na negatywne zdarzenia życiowe. Niektórzy badacze sprzeciwiają się temu ujęciu, podkreślając, że rozważania 
w kontekście resilience jednoznacznie wskazują na zaistnienie trudnych/traumatycznych przeżyć w życiu jednostki i uważają je jako nieodłączny element procesu resilience. Resilience nie może być ich zdaniem postrzegane jako cecha, mimo że ujawnia się w wymiarze behawioralnym. Używając tego terminu w kontekście cechy jednostkowej, w pewnym stopniu przypisuje się danej jednostce odpowiedzialność za poradzenie sobie podczas lub po ekspozycji na trudne doświadczenia. $\mathrm{W}$ takim ujęciu w przypadku poddania się jednostki w obliczu przeciwności losu obarcza się ją odpowiedzialnością za porażkę, co może być stygmatyzujące (Luthar, Cicchetti, Becker 2000).

Resilience jest określana jako cecha jednostki lub rodziny, jak również zdolność do przystosowywania się do przeciwności, wynikającą z zauważalnego sukcesu w pokonywaniu wyzwań. Ta druga perspektywa wynikała z dwóch kryteriów: wyzwanie (ryzyko, stresor, przeciwność losu), przed którym stoi dziecko lub rodzina, a stanowiących poważne zagrożenie dla ich dobrostanu oraz pozytywnej adaptacji (Masten, Cicchetti 2016). W ujmowaniu resilience jako kompetencji jednostki można przyjąć, że jest to zespół „umiejętności skutecznego radzenia sobie ze stresem o dużym nasileniu, polegającym na giętkim (elastycznym), twórczym radzeniu sobie z przeciwnościami; główną rolę odgrywa tu zdolność do oderwania się (bounce-back) od negatywnych doświadczeń i zdolność do wzbudzania pozytywnych emocji" (Heszen, Sęk 2007, s. 173).

W szerszym ujęciu resilience jest definiowane jako proces przystosowywania się jednostki (rodziny, społeczności) i pozytywnego funkcjonowania pomimo ekspozycji na trudne, a nawet traumatyczne przeżycia $\mathrm{w}$ przeszłości lub teraźniejszości. Proces ten jest wielowymiarowy, a składają się na niego między innymi czynniki ryzyka oraz czynniki chroniące, które uczestniczą w procesie pozytywnej adaptacji. W tym ujęciu resilience jest ujmowane jako wielowątkowy proces lub mechanizm ochronny modyfikujący reakcję jednostki na chroniczny stres lub niekorzystne warunki życiowe prowadząc do pozytywnej adaptacji i prawidłowego rozwoju (Luthar, Ziegler 1991). W definicji resilience podkreśla się zatem dwa istotne elementy składowe tego pojęcia - pozytywną adaptację i duże ryzyko. Suniya Luthar (2006) podaje, że resilience to „proces pozytywnej adaptacji jednostki mimo doświadczania poważnych przeciwności lub traumatycznych przeżyć". Przez niektórych badaczy resilience jest określane jako proces osiągania kolejnych norm rozwojowych, adekwatnych do wieku jednostki. Jednostka, dzięki wewnętrznym i zewnętrznym zasobom, pozytywnie przystosowuje się pomimo doświadczania negatywnych zdarzeń i przeciwności losu (Rutter 1987).

Kluczowe jest zatem przyjęcie, iż używając sformułowania resilience należy spełnić trzy warunki: 1) ekspozycja na czynniki, procesy i mechanizmy ryzyka; 
2) działanie czynników, procesów i mechanizmów chroniących;3) pozytywna adaptacja, czyli pozytywny wynik dwóch wcześniej wymienionych przeciwstawnych czynników (Ostaszewski 2014).

Krzysztof Ostaszewski (2014, s. 78) podkreśla, że „to, czy w danym wypadku możemy uznać, że mamy do czynienia z resilience, czy nie, wynika z logicznego wnioskowania, które wyprowadzamy na podstawie przyjętych wcześniej przesłanek. Przesłanki te dotyczą z jednej strony ekspozycji na stresory i czynniki ryzyka, a z drugiej - pozytywnego funkcjonowania mimo tego ryzyka. Jeśli oba te warunki zaistnieją, wówczas mówimy o resilience".

Badacze wskazują na brak dokładnych określeń i zmiennych definiujących resilience. Podkreśla się związek pomiędzy tym konstruktem a takimi zmiennymi, jak poczucie mistrzostwa, optymizm, poleganie na Bogu (Littrell, Beck 1999) czy poczucie własnej wartości, wsparcie społeczne, umiejętność rozwiązywania problemów i strategie radzenia sobie (Dumont, Provost 1999). Inne badania natomiast powiązują resilience z trzema czynnikami: poczuciem własnej skuteczności, well-defined faith lives oraz zdolnością do radzenia sobie z barierami i przeszkodami (Bachay, Cingel 1999).

George Bonanno (Southwick, Bonanno i in. 2014) proponuje, aby resilience definiować jako stabilną trajektorię pozytywnego funkcjonowania po niekorzystnym zdarzeniu życiowym. Trajektoria resilience charakteryzuje się tym, iż po krótkim okresie nierównowagi spowodowanym traumatycznym przeżyciem jednostka wykazuje pozytywne funkcjonowanie. Za traumę można uznać utratę bliskiej osoby, bezdomność, wojnę i inne konsekwencje kryzysów gospodarczych, naturalnych i politycznych (Masten i in. 2015).

\section{POJĘCIA ZWIĄZANE Z RESILIENCE}

W rozważaniach nad koncepcją resilience należy wskazać na kluczowe pojęcia z nią związane. Resilience wyjaśnia fenomen pozytywnej adaptacji w obliczu trudności czy też przeciwności losu, wskazując na istotną rolę czynników ryzyka i czynników chroniących. Jednym z kluczowych pojęć w tej koncepcji jest ryzyko, które w kontekście angielskiego resilience jest definiowane najczęściej terminem adversity - niepomyślne, niekorzystne warunki życiowe, nieszczęście, przeciwności losu (dorastanie w ubóstwie, w rodzinie dotkniętej problemem alkoholowym, w kraju lub regionie dotkniętym wojną) (Ostaszewski 2014). W przypadku badań nad resilience ryzyko jest postrzegane w trzech kategoriach - jako czynniki ryzyka i ich nagromadzenie, jako ekspozycja na chroniczny stres lub/oraz jako ekspozycja na traumatyczne wydarzenia (Masten 2001, Rutter 2000). 
Za czynniki ryzyka można przyjąć między innymi bycie dzieckiem rodzica ze schizofrenią (15 krotnie zwiększa ryzyko zachorowania na schizofrenie - Fraser i in. 1999), niski status społeczno-ekonomiczny (ang. socioeconomic status, SES), bezpośrednie narażenie na złe traktowanie lub przemoc, masową traumę społeczności, wystąpienie rozwodu, niską masę urodzeniową. Badania dowodzą, że w przypadku doświadczenia pojedynczych lub skumulowanych negatywnych zdarzeń życiowych można mówić o wzroście ryzyka złych wyników w zakresie wielu wskaźników rozwoju, w tym kompetencji psychospołecznych, psychopatologii i zdrowia (Masten, Wright 1998; Rutter 1979, 1990; Seifer, Sameroff 1987). Większość czynników ryzyka indeksuje się w sposób ciągły - jest dwubiegunowa - to znaczy jeden $\mathrm{z}$ biegunów ma pozytywny koniec związany z pozytywnymi wynikami, a drugi - negatywny (np. posiadanie niskiego versus wysokiego poziomu wykształcenia).

Czynniki ryzyka mogą być środowiskowe, sytuacyjne lub socjoekonomiczne. Do środowiskowych czynników ryzyka możemy zaliczyć przewlekłe problemy lub zaburzenia psychiczne rodziców. Tego typu czynniki charakteryzuje zazwyczaj długotrwałe działanie, najczęściej poza kontrolą jednostki (Sęk, Brzezińska 2008). Czynniki sytuacyjne dotyczą krytycznych życiowych wydarzeń, jakich doświadczają jednostki bądź też ogólnie sytuacji stresujących. Do czynników socjoekonomicznych natomiast należy zaliczyć niski poziom wykształcenia rodziców, niskie dochody lub bezrobocie w rodzinie, przynależność do mniejszości etnicznej. Ann Masten (2001) w sensie statystycznym czynniki ryzyka postrzega jako korelaty lub predyktory chorób lub nieprawidłowych zachowań. Rutter (1979) do czynników ryzyka zaliczył: konflikty małżeńskie, niski status socjoekonomiczny rodziny, wielodzietność w rodzinie, przestępczość ojców, choroby psychiczne matek i korzystanie z pomocy społecznej. Uzyskane przez Ruttera wyniki badań wskazały, że wystąpienie jednego czynnika ryzyka nie zwiększa prawdopodobieństwa wystąpienia zaburzeń psychicznych u dzieci, ale już kombinacja dwóch dowolnych czynników - zwiększa je czterokrotnie w porównaniu do populacji dzieci niedoświadczających tychże czynników.

Kolejny, istotny w aspekcie resilience termin to czynniki chroniące. W literaturze przedmiotu (za: Borucka, Ostaszewski 2008) można odnaleźć trzy grupy tych czynników. Po pierwsze są to cechy indywidualne, takie jak wysoka samoocena, poczucie własnej skuteczności, łagodne usposobienie, dobre funkcjonowanie edukacyjne, wiara, talenty. Druga kategoria dotyczy czynników rodzinnych zgodność rodziny, brak konfliktów małżeńskich i rodzicielskich, dobre relacje między członkami rodziny, dobra sytuacja materialna rodziny. W trzeciej kategorii znajdują się czynniki zewnętrzne, do których można zaliczyć dobre i bezpieczne sąsiedztwo, posiadanie mentora, przynależność do organizacji prospołecznych, 
uczęszczanie do pozytywnie funkcjonującej szkoły. Garmezy (1971) za czynniki chroniące uznał dobre relacje z rówieśnikami i posiadanie kompetencji osobistych, a Rutter (1979) przyjmuje, że czynnikami chroniącymi są: pozytywny klimat szkoły, odpowiednie praktyki rodzicielskie, kontrolowanie sytuacji stresujących, dobre relacje ze znaczącymi dorosłymi oraz punkty zwrotne w karierze.

Niektórzy badacze (Luthar, Zelezo 2003) podają, że czynniki ryzyka i czynniki chroniące w niektórych przypadkach mogą znajdować się na przeciwległych krańcach jednego kontinuum. Można tak określić na przykład poziom wykształcenia niski jest ujmowany w kategoriach czynnika ryzyka, natomiast wysoki - jako czynnik chroniący. Podobnie status socjoekonomiczny rodziny - wraz z jego wzrostem zwiększają się możliwości jednostki czy też rodziny lepszego funkcjonowania, na przykład zdrowego odżywiania, lepszego dostępu do opieki medycznej, lepszych warunków edukacji czy bezpieczniejszego miejsca zamieszkania. Jednak czynnik, jakim jest wiek matki, nie może być już ujmowany jako kontinuum. Młody wiek matki może być uznany jako czynnik ryzyka, ale już w przypadku starszych kobiet nie będzie ujmowany jako czynnik chroniący. Podobnie niektóre czynniki można uznać za chroniące, jeśli ich poziom umiejscowiony jest pośrodku kontinuum. Tak jest w przypadku samooceny, która zarówno niska, jak i nadmiernie wysoka nie będzie stanowiła czynnika chroniącego, gdyż najbardziej ułatwiający adaptację jest średni poziom samooceny (Luthar, Zelezo 2003).

Pozytywna adaptacja to jedno $\mathrm{z}$ elementarnych pojęć w kontekście resilience. Pierwszy sposób definiowania pozytywnej adaptacji odnosi się do zewnętrznych oczekiwań rozwojowych. Przejawem pozytywnej adaptacji w dzieciństwie będzie zatem wykształcenie bezpiecznego związku ze znaczącymi dorosłymi, a w przypadku dzieci w wieku szkolnym - pozytywne funkcjonowanie w roli ucznia, nawiązywanie relacji z rówieśnikami, pozytywne radzenie sobie w sytuacjach trudnych i stresujących. W wieku adolescencji przejawem pozytywnej adaptacji będzie umiejętność nawiązywania przyjaźni i utrzymywania pozytywnych relacji $\mathrm{z}$ rówieśnikami, radzenie sobie z wymaganiami szkolnymi, unikanie zachowań ryzykownych oraz podejmowanie zaangażowania społecznego. Wczesna dorosłość to okres, w którym przejawem pozytywnej adaptacji będzie uzyskanie wykształcenia, podjęcie pracy zawodowej, założenie rodziny (Masten, Obradovic 2006). Drugi sposób definiowania pozytywnej adaptacji odnosi się do założenia, że jej przejawem nie jest normatywny rozwój, a brak objawów psychopatologii, zaburzeń zachowania czy problemów psychicznych (Masten 2001). Ostaszewski podkreśla, że sukcesów młodego człowieka należy dopatrywać się w kategoriach edukacyjnych, zdrowotnych, behawioralnych i społecznych: „Definiowanie pozytywnej adaptacji musi brać pod uwagę fakt, że jedna i ta sama osoba może odnosić sukcesy w pewnym obszarze swojego psychospołecznego funkcjonowania, a nie mieć ich w innym. [...] 
Jej (pozytywnej adaptacji - dop. autora) wyczerpujący pomiar powinien w miarę możliwości uwzględniać kombinację kryteriów zewnętrznych i wewnętrznych z różnych obszarów funkcjonowania młodego człowieka" (2014, s. 83).

\section{MOŻLIWOŚCI POZNAWCZE I OGRANICZENIA KONCEPCJI RESILIENCE}

W ostatniej dekadzie wzrosło zainteresowanie resilience zarówno w aspekcie indywidualnych jednostek, jak i resilience rodziny (ang. family resilience) czy społeczności (ang. community resilience). Sama koncepcja daje szerokie możliwości poznawcze, istotne dla zrozumienia złożonych procesów pozwalających przystosować się i pozytywnie funkcjonować w obliczu trudnych lub traumatycznych wydarzeń. Wraz z kolejnymi badaniami przyjmowano coraz szerszą perspektywę uwzględniającą wiek rozwojowy jednostki, obejmującą wzajemne interakcje czynników biologicznych, psychologicznych, społecznych i środowiskowych, a mających związek nie tylko z nieprawidłowym rozwojem, ale również z wykazywaniem pozytywnego funkcjonowania pomimo niekorzystnych warunków (Cicchetti 2006, Rutter 2009). Współczesne przemiany społeczne, polityczne, gospodarcze niosą za sobą wiele wyzwań dla adaptacji jednostki, rodzin i całych społeczeństw. W kontekście prawidłowego rozwoju dziecka koncepcja resilience pozwala na poznanie mechanizmów funkcjonowania dzieci maltretowanych, żyjących w ubóstwie, adoptowanych, żyjących w rodzinach zastępczych, dyskryminowanych i doświadczających innych przeciwności losu (por. Cichetti 2013, Zeanah i in. 2017). Badania ukierunkowane są również na procesy rodzinne, które mogą decydować o resilience dzieci i rodzin (Walsh 2016). Podkreśla się rolę resilience w edukacji, w tym - w osiąganiu sukcesów w nauce pomimo doświadczania przeciwności niezależnych od jednostki. Dla pedagogiki i praktyki psychologicznej badania w zakresie koncepcji resilience pozwalają na zaplanowanie pracy i podjęcie ukierunkowanych działań mających na celu wsparcie uczniów narażonych na czynniki ryzyka (Smulczyk 2016). Ostaszewski (2014) przedstawił szerokie możliwości wykorzystania koncepcji resilience w badaniach młodzieży i podczas formułowania programów profilaktycznych i wychowawczych. Wskazuje się również na możliwości wykorzystania koncepcji resilience w profilaktyce niedostosowania społecznego i resocjalizacji, podkreślając jej spójność z socjo-ekologiczną koncepcją rozwoju człowieka (Mudrecka 2013).

Pomimo dużej popularności koncepcji resilience należy podkreślić brak precyzji i jednoznaczności podczas definiowania zarówno samego pojęcia, jak i jego głównych składowych. Często cytowana definicja określa resilience jako „albo proces pozytywnej adaptacji w niekorzystnych lub zagrażających okolicznościach, albo 
własność umożliwiająca tę adaptację, albo jej wynik” (Masten, Best, Garmezy 1990, s. 426). Metaanalizy dotyczące resilience pozostają rzadkie z powodu niespójności dotyczącej definiowania i pomiaru resilience w literaturze (Masten, Cicchetti 2016), a problem ten staje się jeszcze większy w aspekcie postrzegania resilience jako koncepcji systemowej. Niejednoznacznie definiowane bywają również kluczowe dla resilience takie pojęcia, jak pozytywna adaptacja, czynniki ryzyka lub czynniki chroniące, a za zagrożenie dla zdrowia i rozwoju jest uznawane szerokie spektrum okoliczności. Przyjmowane są tu zarówno poważne problemy charakteryzujące rodziców (na przykład choroby psychiczne lub uzależnienia), przez podwyższone ryzyko, jakie niesie za sobą miejsce zamieszkania, funkcjonowanie i rozwój psychospołeczny dzieci doświadczających silnego i długotrwałego stresu, po traumatyczne wydarzenia obejmujące całe społeczności - wojny, terroryzm, katastrofy naturalne (Luthar 2006). Oprócz wątpliwości co do definiowania resilience i zakres pojęciowy stosowanej terminologii, trudności nastręcza przysparza również operacjonalizacja i pomiar kluczowych zmiennych.

W polskich badaniach nad resilience można wskazać zbyt duży chaos definicyjny. Badacze przyjmują różne tłumaczenia tego pojęcia oraz jego definicje operacyjne, kierując się zazwyczaj subiektywnym postrzeganiem. Być może należy pozostać przy angielskim oryginalnym sformułowaniu resilience lub rozważyć, czy, aby ujednolicić polską terminologię, wprowadzić spolszczenie tego terminu rezyliencja (Junik 2011). Aby dojść do jednoznaczności w tej kwestii potrzebne są badania empiryczne.

Przywołane możliwości poznawcze i ograniczenia koncepcji resilience wskazują na potrzebę ustalenia jednolitych ram teoretyczno-empirycznych. Konieczność integracji wiedzy teoretycznej i praktycznej w przypadku zjawiska resilience jest postulatem umożliwiającym dokonywanie poprawnych analiz oraz wyprowadzanie prawidłowych wniosków.

\section{LITERATURA}

Bachay J.B., Cingel P.A., 1999, Restructuring Resilience: Emerging Voices. „Affilia”, 14(2), 162-175. DOI: 10.1177/08861099922093581.

Block J., Kremen A.M., 1996, IQ and Ego-Resiliency: conceptual and empirical connections and separateness. „Journal of Personality and Social Psychology”, 70, 349-361.

Borucka A., Ostaszewski K., 2008, Koncepcja resilience. Kluczowe pojęcia i wybrane zagadnienia. „Medycyna Wieku Rozwojowego”, 12(2), 587-597.

Cicchetti D., 2006, Development and Psychopathology. W: D. Cicchetti (red.), Developmental Psychopathology (2 wyd.), Theory and Method. New York: Wiley, vol. 1, 1-23. 
Cicchetti D., 2013, Annual research review: Resilient functioning in maltreated children-past, present, and future perspectives. „Journal of Child Psychology and Psychiatry”, 54, 402-422. DOI: 10.1111/j.1469-7610.2012.02608.x

Dumont M., Provost M.A., 1999, Resilience in Adolescents: Protective Role of Social Support, Coping Strategies, Self-Esteem, and Social Activities on Experience of Stress and Depression. „Journal of Youth and Adolescence”, 28, 343-363. DOI: 10.1023/A:1021637011732.

Fraser M.W., Richman J.M., Galinsky M.J., 1999, Risk, protection, and resilience: Toward a conceptual framework for social work practice. „Social Work Research”, 23(3), 131-143.

Garmezy N., 1971, Vulnerability research and the issue of primary prevention. „American Journal of Orthopsychiatry", 41(1), 101-116. DOI: 10.1111/j.1939-0025.1971. tb01111.x.

Garmezy N., 1985, Stress-Resistant Children: The Search for Protective Factors. W: J. Stevenson (red.), Recent Research in Developmental Psychopathology. Oxford-New York-Toronto-Sydney-Paris-Frankfurt: Pergamon Press, 213-234.

Gottesman I.I., 1974, Developmental Genetics and Ontogenetic Psychology: Overdue Detente and Propositions from a Matchmaker. W: A.D. Pick (red.), Minnesota Symposia on Child Psychology. Minneapolis: The University of Minnesota Press, 55-80. Henry C.S., Morris A., Harrist A.W., 2015, Family Resilience: Moving into the Third Wave February. „Family Relations”, 64(1), 22-43. DOI: 10.1111/fare.12106

Herman M., Kalestyński A., Widomski L., 2012, Podstawy fizyki dla kandydatów na wyższe uczelnie i studentów. Warszawa: Wydawnictwo Naukowe PWN.

Heszen I., Sęk H., 2007, Psychologia zdrowia. Warszawa: Wydawnictwo Naukowe PWN. Junik W., 2011, Zjawisko rezyliencji - wybrane problem metodologiczne. W: W. Junik (red.), Resilience. Teoria - Badania - Praktyka. Warszawa: Wydawnictwo Edukacyjne Parpamedia, 47-55.

Kaczmarek Ł., 2011, Skala Sprężystości Psychicznej - polska adaptacja Ego Resiliency Scale. „Czasopismo Psychologiczne”, 17, 263-265.

Littrell J., Beck E., 1999, Perceiving oppression: Relationships with resilience, self-esteem, depressive symptoms, and reliance on God in African-American homeless men. „J. Soc. \& Soc. Welfare”, 26, 137.

Luthar S.S., 2006, Resilience in development: A synthesis of research across five decades. W: D. Cicchetti, D.J. Cohen (red.), Developmental psychopathology: Risk, disorder, and adaptation, Hoboken, NJ, US: John Wiley \& Sons Inc, 739-795.

Luthar S.S., Zigler E., 1991, Vulnerability and competence: A Review of research on resilience in childhood. „American Journal of Orthopsychiatry”, 61(1), 6-22.

Luthar S.S, Cicchetti D., Becker B., 2000, The Construct of Resilience: A Critical Evaluation and Guidelines for Future Work. „Child Development”, 71(3), 543-562. 
Luthar S.S., Zelazo, L.B., 2003, Research on Resilience. An Integrative Review. W: Luthar, SS., (red.) Resilience and Vulnerability. Cambridge University Press; s. 510-549.

Ogińska-Bulik N., Juczyński Z., 2011, Prężność u dzieci i młodzieży: charakterystyka i pomiar - polska skala SPP-18. „Polskie Forum Psychologiczne”, 16(1), 7-28.

Ostaszewski K., 2014, Zachowania ryzykowne młodzieży w perspektywie mechanizmów resilience. Warszawa, Instytut Psychiatrii i Neurologii.

Martin A., Njoroge W., 2005, Resilience and vulnerability: Adaptation in the context of childhood adversities. „American Journal of Psychiatry”, 162(8), 1553-a.

Masten A.S., 1989, Resilience in development: Implications of the study of successful adaptation for developmental psychopathology: Rochester Symposium on Developmental Psychopatholo. W: D. Cicchetti (red.), The emergence of a discipline: Rochester Symposium on Developmental Psychopathology, Hillsdale, NJ: Lawrence Erlbaum, vol. 1, 261-294.

Masten A.S., 2001, Ordinary magic. „American Psychologist”, 56(3), 227-238.

Masten A.S., 2018, Resilience Theory and Research on Children and Families: Past, Present, and Promise. "Journal of Family Theory and Review”. Vol.10, Issue1 Special Issue: TENTH ANNIVERSARY SPECIAL ISSUE: Family Theory: Past, Present, Future. DOI: 10.1111/jftr.12255.

Masten A.S., Tellegen A., 2012, Resilience in developmental psychopathology: contributions of the Project Competence Longitudinal Study. „Development and Psychopathology", 24(2), 345-361. DOI: 10.1017/S095457941200003X.

Masten A.S., Best K. M., Garmezy N., 1990, Resilience and development: Contributions from the study of children who overcome adversity. „Development and Psychopathology", 2(4), 425-444. DOI: 10.1017/S0954579400005812.

Masten A.S., Cicchetti D., 2016, Resilience in development: Progress and transformation. W: D. Cicchetti (red.), Developmental psychopathology: Risk, resilience, and intervention. Hoboken, NJ, US: John Wiley and Sons Inc., 271-333. DOI: 10.1002/9781119125556.devpsy406.

Masten A.S., Narayan A.J., Silverman, W.K., Osofsky J.D., 2015, Children in war and disaster. W: M.H. Bornstein, T. Leventhal, R.M. Lerner (red.), Handbook of child psychology and developmental science: Ecological settings and processes. Hoboken, NJ, US: John Wiley \& Sons Inch, 704-745. DOI: 10.1002/9781118963418.

Masten A.S., Wright M.O., 1998, Cumulative risk and protection models of child maltreatment. „Journal of Aggression, Maltreatment and Trauma”, 2(1), 7-30. DOI: 10.1300/J146v02n01_02.

Masten A., Obradović J., 2006, Competence and resilience in development. „Annals of the New York Academy of Sciences”, 1094, 13-27.

Mudrecka I., 2013, Wykorzystanie koncepcji „resilience” w profilaktyce niedostosowania społecznego i resocjalizacji. „Resocjalizacja Polska” (Polish Journal of Social Rehabilitation), nr 5, 49-61. 
Reid D., Resilience Theory: What Research Articles in Psychology Teach Us, opublikowano: https://positivepsychology.com/resilience-theory/ [dostęp: 25.02.2019]. Rutter M., 1979, Protective factors in children's responses to stress and disadvantage. W: M. Kent, J. Rolf (red.), Primary prevention of psychopathology, Vol. III: Social competence in children. Hanover: University Press of New England, 49-74.

Rutter M., 1987, Psychosocial Resilience and Protective Mechanisms. „American Journal Orthopsychiatry", 57(3), 316-331.

Rutter M., 2000, Resilience reconsidered: Conceptual considerations, empirical findings, and policy implications. W: J. Shonkoff, S. Meisels (red.), Handbook of Early Childhood Intervention. Second edition. Cambridge University Press, 651-682.

Rutter M., 2009, Understanding and testing risk mechanisms for mental disorders. „Child Psychology and Psychiatry”, vol. 50, nr 1-2, 44-52.

Ryś M., Trzęsowska-Greszta E., 2018, Kształtowanie się i rozwój odporności psychicznej. „Kwartalnik Naukowy”, 2(34).

Sapienza J., Masten A., 2011, Understanding and promoting resilience in children and youth. „Current Opinion in Psychiatry”, 24, 267-273.

Seifer R., Sameroff A.J., 1987, Multiple determinants of risk and invulnerability. W: E.J. Anthony, B.J. Cohler (red.), The Guilford psychiatry series. The invulnerable child New York. NY, US: Guilford Press, 51-69.

Sęk H., Brzezińska A.I., 2008, Podstawy pomocy psychologicznej. W: J. Strelau, D. Doliński (red.), Psychologia. Podręcznik akademicki, t. 2. Gdańsk: Gdańskie Wydawnictwo Psychologiczne, 735-784.

Smulczyk M., 2016, Resilience a edukacja. Rola fenomenu skutecznej adaptacji w osiagnnięciach szkolnych. „Forum Oświatowe”, 28(2), 203-222.

Southwick S.M., Bonanno G.A., Masten A.S., Panter-Brick C., Yehuda R., 2014, Resilience definitions, theory, and challenges: interdisciplinary perspectives. „European journal of psychotraumatology", 5(1), 25338.

Szwajca K., 2014, Sprężystość (resilience) i odpowiedzi na doświadczenia urazowe fascynujący i trudny obszar badań. „Psychiatria Polska”, 48(3), 563-572.

Uchnast Z., 1998, Prężność osobowa a egzystencjalne wymiary wartościowania. „Roczniki Psychologiczne", t. I. 7-27.

Walsh F., 2016, Family resilience: A developmental systems framework. „European Journal of Developmental Psychology", 13(3), 313-324. DOI: 10.1080/17405629.2016.1154035.

Werner E., 2005, Resilience and Recovery. Findings from the Kauai longitudinal study. „Research, Politycy and Practice in Chlidren's Mental Health”, vol. 19, nr 1, 11-14.

Zeanah C.H., Humphreys K.L., Fox N.A., Nelson C.A., 2017, Alternatives for abandoned children: Insights from the Bucharest Early Inter-vention Project. „Current Opinion in Psychology”, 15, 182-188. DOI: 10.1016/j.copsyc.2017.02.024. 


\title{
RESILIENCE IN A TRADITIONAL AND CONTEMPORARY CONTEXT
}

\begin{abstract}
In this article out lines the koncept of resilience chich broadly relates to the adaptability of person, family or en tire communities in the face of adversity or traumatic events. The genesis of the conceptof resilience was pointed out. Norman Garmezy, Emmy Werner and Michael Rutter were pointed out as precusors to resilience research and a synthetic description of their research was also made. The considerations taken in this article are intended to show the complexity of the resilience construct Istel and the concepts related to it - positive adaptation, risk and protective factors. Cognitive possibilities and limitations in the use of the resilience koncept were also analyzed, emphasizing the Reed to establish uniform theoretical and empirical frameworks.
\end{abstract}

Keywords: resilience, positive adaptation, risk factors, protective factors 